\title{
Evidence for Resident Memory T Cells in Rasmussen Encephalitis
}

\author{
Geoffrey C. Owens ${ }^{1 *}$, Julia W. Chang ${ }^{1,2}$, My N. Huynh ${ }^{1}$, Thabiso Chirwa ${ }^{1}$, \\ Harry V. Vinters ${ }^{2,3,4,5}$ and Gary W. Mathern ${ }^{1,2,5,6}$
}

\begin{abstract}
'Department of Neurosurgery, David Geffen School of Medicine at UCLA, Los Angeles, CA, USA, ${ }^{2}$ Intellectual and Developmental Disabilities Research Center, David Geffen School of Medicine at UCLA, Los Angeles, CA, USA, ${ }^{3}$ Department of Pathology and Laboratory Medicine, David Geffen School of Medicine at UCLA, Los Angeles, CA, USA, ${ }^{4}$ Department of Neurology, David Geffen School of Medicine at UCLA, Los Angeles, CA, USA, ${ }^{5}$ Brain Research Institute, David Geffen School of Medicine at UCLA, Los Angeles, CA, USA, ${ }^{6}$ Mattel Children's Hospital, Los Angeles, CA, USA
\end{abstract}

\section{OPEN ACCESS}

Edited by:

Björn Tackenberg,

Philipps-Universität Marburg,

Germany

Reviewed by:

Nancy Monson,

University of Texas Southwestern

Medical Center, USA

Gerd Meyer Zu Horste,

Westfälische Wilhelms-Universität

Münster, Germany

*Correspondence:

Geoffrey C. Owens

geoffreyowens@mednet.ucla.edu

Specialty section: This article was submitted to Multiple Sclerosis and Neuroimmunology, a section of the journal Frontiers in Immunology

Received: 16 September 2015 Accepted: 09 February 2016

Published: 23 February 2016

Citation:

Owens GC, Chang JW, Huynh MN,

Chirwa T. Vinters HV and

Mathern GW (2016) Evidence for

Resident Memory T Cells in

Rasmussen Encephalitis.

Front. Immunol. 7:64.

doi: 10.3389/fimmu.2016.00064
Rasmussen encephalitis (RE) is a rare pediatric neuroinflammatory disease of unknown etiology characterized by intractable seizures, and progressive atrophy usually confined to one cerebral hemisphere. Surgical removal or disconnection of the affected cerebral hemisphere is currently the only intervention that effectively stops the seizures. Histopathological evaluation of resected brain tissue has shown that activated brain resident macrophages (microglia) and infiltrating $T$ cells are involved in the inflammatory reaction. Here, we report that $T$ cells isolated from seven RE brain surgery specimens express the resident memory $T$ cell $\left(T_{R M}\right)$ marker CD103. CD103 was expressed by $>50 \%$ of $\mathrm{CD}^{+} \alpha \beta$ T cells and $\gamma \delta$ T cells irrespective of the length of time from seizure onset to surgery, which ranged from 0.3 to 8.4 years. Only $\sim 10 \%$ of $\mathrm{CD}^{+} \alpha \beta$ were $\mathrm{CD}_{103^{+}}$, which was consistent with the observation that few $\mathrm{CD} 4^{+} \mathrm{T}$ cells are found in RE brain parenchyma. Clusters of T cells in brain parenchyma, which are a characteristic of RE histopathology, stained for CD103. Less than $10 \%$ of $T$ cells isolated from brain specimens from eight surgical cases of focal cortical dysplasia (FCD), a condition that is also characterized by intractable seizures, were $\mathrm{CD}_{103^{+}}$. In contrast to the RE cases, the percent of $\mathrm{CD}_{103}{ }^{+} \mathrm{T}$ cells increased with the length of time from seizure onset to surgery. In sections of brain tissue from the FCD cases, T cells were predominantly found around blood vessels, and did not stain for CD103. The presence of significant numbers of $T_{R M}$ cells in RE brain irrespective of the length of time between clinical presentation and surgical intervention supports the conclusion that a cellular immune response to an as yet unidentified antigen(s) occurs at an early stage of the disease. Reactivated $T_{\mathrm{RM}}$ cells may contribute to disease progression.

Keywords: Rasmussen encephalitis, focal cortical dysplasia, resident memory T cells, alpha beta T cells, gamma delta T cells

\section{INTRODUCTION}

Rasmussen encephalitis (RE) is a rare chronic neuroinflammatory disease that primarily affects young children $(1,2)$. In the acute stage of the disease, RE patients present with intractable partial (focal) seizures that may spread to the rest of the brain. Hyperintensity in T2/FLAIR magnetic resonance images usually in one cerebral hemisphere is indicative of inflammation and atrophy 
(3). The inflammation may spread through the affected cerebral hemisphere, but generally does not cross over to the contralateral hemisphere (3). In the residual stage of the disease, there is significant unilateral brain atrophy and permanent neurological deficits that may affect motor and sensory systems. Intravenous immunoglobulins and tacrolimus can slow the destruction of brain tissue, but cannot reverse the intractable seizures (4). Early treatment of a presumptive RE case with ganciclovir was reported to ameliorate the seizures (5). Ultimately, surgical removal or disconnection of the affected cerebral hemisphere is the only intervention that stops the seizures, but inevitably leaves the patient with some functional deficits. A better understanding of the inflammatory processes that occur in RE may lead to the development of alternative non-surgical treatments.

The inflammatory reaction in RE involves both activated brain resident macrophages (microglia) and $\mathrm{T}$ cells (6-9). Histopathological examination of resected brain tissue and brain biopsies show $\mathrm{T}$ cells in perivascular spaces, leptomeninges, and in small clusters scattered throughout the affected grey and white matter $(7,9)$. Here, we report that many of the $T$ cells in the parenchyma of affected RE brain tissue at the time of surgery are resident memory $\mathrm{T}$ cells $\left(\mathrm{T}_{\mathrm{RM}}\right)$ as evidenced by the expression of $\mathrm{CD} 103$, the $\alpha \mathrm{E}$ integrin subunit. $\mathrm{T}_{\mathrm{RM}}$ cells are a distinct population of memory cells that persist in non-lymphoid tissues (NLTs) long after the resolution of an immune response (10-14). They develop in situ from $\mathrm{T}$ cells that enter an inflamed tissue during the effector stage of an immune response (15). In animal models of virus infection, the establishment of $\mathrm{T}_{\mathrm{RM}}$ cells is controlled by regulatory $\mathrm{T}$ cells $(16,17)$. It has also been shown in mice that $\mathrm{T}_{\mathrm{RM}}$ cells respond more rapidly than circulating central memory $\mathrm{T}$ cells to the local reoccurrence of a pathogen (14). The binding of $\alpha E \beta 7$ integrin heterodimers to E-cadherin on epithelial cells is thought to contribute to the retention of $\mathrm{T}_{\mathrm{RM}}$ cells in NLTs (18), although not all $\mathrm{T}_{\mathrm{RM}}$ cells express CD103 (19). $\alpha \mathrm{E} \beta 7$ integrin is also involved in the maturation of the immunological synapse and promotes the polarization of cytotoxic T cells (20). The potential significance of $\mathrm{T}_{\mathrm{RM}}$ cells in $\mathrm{RE}$ brain is discussed.

\section{MATERIALS AND METHODS}

All of the surgical specimens used in this study were obtained under IRB approval (UCLA IRB nos. 11-00030 and 13-001213), and with informed consent. In accordance with HIPAA guidelines, all specimens and patient data were de-identified. There were no exclusion criteria. The clinical information for five of the seven RE cases and for four of the eight focal cortical dysplasia (FCD) cases in the present study has been previously published (21). The data for all of the cases are provided in Table S1 in Supplementary Material.

\section{Flow Cytometry}

The isolation and cryopreservation of the brain-infiltrating lymphocytes (BILs) have been previously described (21). In brief, fresh brain tissue was finely minced in dissociation solution (HBSS with $20 \mathrm{mM}$ HEPES pH7.0, $5 \mathrm{mM}$ glucose, and $50 \mathrm{U} / \mathrm{ml}$ penicillin/ streptomycin), then digested overnight at room temperature in dissociation solution containing $0.5 \mathrm{mg} / \mathrm{ml}$ Type IV collagenase
(Worthington Biochemical Corp., Lakewod, NJ, USA) and 5\% filtered human serum (Mediatech Inc., Manassas, VA, USA). BILs were obtained by fractionation on a $30 \%$ : $70 \%$ Percoll $^{\circledR}$ (SigmaAldrich, St. Louis, MO, USA) step gradient in RPMI containing $20 \mathrm{mM}$ HEPES. BILs were stained with the following antibodies: APC-efluor ${ }^{\circledR}$ 780-conjugated CD3 (clone UCHT1; eBioscience Inc., San Diego, CA, USA), PE/Cy7-conjugated CD4 (clone SK3; eBioscience Inc.), PerCP/Cy5.5-conjugated CD8 (clone RPA-T8; eBioscience Inc.), APC-conjugated TCR $\alpha \beta$ (clone IP26; eBioscience Inc.), FITC-conjugated TCR $\gamma \delta$ (clone B1.1; eBioscience Inc), and PE-conjugated CD103 (clone B-Ly7; eBioscience Inc). Data were acquired on an analytical LSRII flow cytometer (Becton Dickinson, San Jose, CA, USA), and were analyzed with FlowJo software (TreeStar Inc., Ashland, OR, USA); histograms were exported into CorelDrawX6 (Corel Corporation, Ottawa, ON, Canada). Statistical analysis and graphing utilized R-project programs (www.r-project.org).

\section{Immunocytochemistry}

Serial sections $(5 \mu \mathrm{m})$ of paraffin-embedded involved tissue were deparaffinized; antigen retrieval was accomplished by microwaving for $20 \mathrm{~min}$ in buffered citrate $(10 \mathrm{mM}, \mathrm{pH} 6.0)$. Sections were blocked for $1 \mathrm{~h}$ (Impress Kit, Vector Laboratories, Burlingame, CA, USA), then incubated overnight at $4^{\circ} \mathrm{C}$ with a rabbit anti-human CD3 polyclonal antibody (1:800, Dako North America, Inc., Carpinteria, CA, USA) or a rabbit anti-human CD103 monoclonal antibody (clone EPR4166, 1:500, Abcam, Cambridge, MA, USA). Sections were subsequently incubated with a peroxidase-conjugated anti-rabbit secondary antibody (1: 300 , Impress Kit, Vector Laboratories) for $1 \mathrm{~h}$ at room temperature. Staining was visualized by adding 3, 3'-diaminobenzidine (DAB) (MP Biomedicals, Santa Ana, CA, USA), followed by counterstaining with hematoxylin. Images were acquired using an Aperio ScanScope XT scanner (Aperio, Vista, CA, USA), then transferred to CorelDRAWX6 (Corel Corporation). For immunofluorescence microscopy, fixed free-floating $30 \mu \mathrm{m}$ cryostatcut sections were blocked in PBS with 5\% normal goat serum (Vector Laboratories) and $0.3 \%$ Triton $\mathrm{X}-100$ for $1 \mathrm{~h}$, then incubated in mouse anti-human CD8 (clone C8/144B, 1: 100, Dako) and anti-human CD103 monoclonal antibody (clone EPR4166, 1:500, Abcam) overnight at $4^{\circ} \mathrm{C}$ followed by incubation in Alexa Fluor $^{\circledR} 488$ goat anti-rabbit and Alexa Fluor ${ }^{\circledR} 568$ goat anti-mouse secondary antibodies (1:1000, Life Technologies, Carlsbad, CA, USA) for $1 \mathrm{~h}$ at room temperature. Sections were mounted in ProLong ${ }^{\circledR}$ Gold anti-fade reagent containing DAPI (Life Technologies). Images were acquired using an Olympus spinning disk confocal microscope (Olympus America, Inc., Center Valley, PA, USA) under the control of SlideBook ${ }^{\mathrm{TM}}$ image acquisition and analysis software (Intelligent Imaging Innovations, Inc., Denver, CO, USA), then transferred to CorelDRAWX6 (Corel Corporation).

\section{RESULTS}

The clinical details of the surgical cases in this study are provided in Table S1 in Supplementary Material. BILs previously isolated from five RE brain surgery specimens (21) and from two new RE 

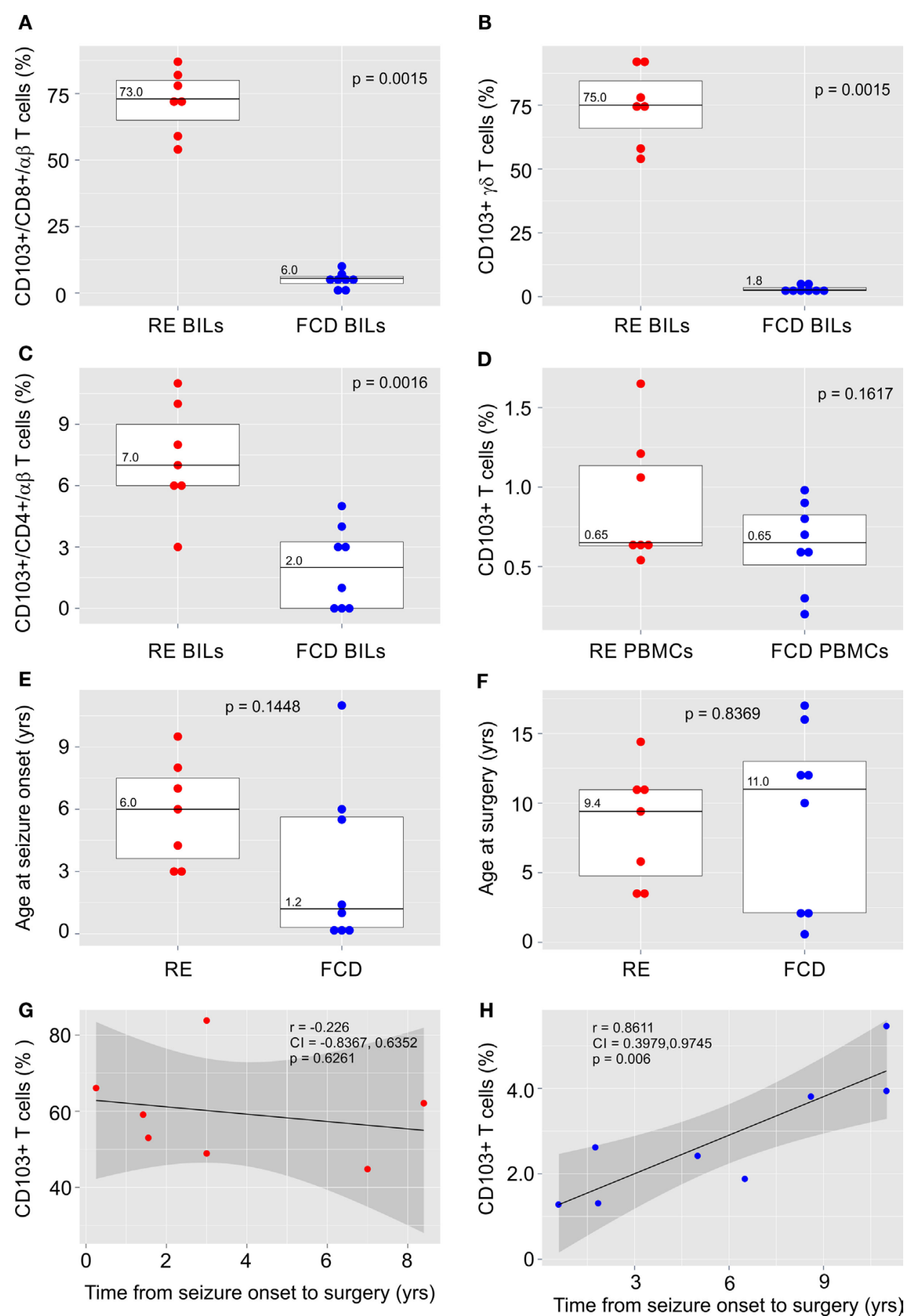

FIGURE 1 | CD103 expression by T cells isolated from RE and FCD brain specimens. Box plots with median values showing the percent of CD $8^{+} \alpha \beta$ T cells (A), $\gamma \delta$ T cells (B) and CD4+ $\alpha \beta$ T cells (C) in brain-infiltrating lymphocytes (BILs) that are CD103 $^{+}$, and (D) the percent of T cells that express CD103 in peripheral blood lymphocytes (PBMCs) from the same patients. In (E,F) box plots with median values of patient ages at seizure onset and at surgery are shown. Red dots correspond to individual RE cases $(n=7)$, and blue dots correspond to individual FCD cases $(n=8)$. Calculated $p$-values (Mann-Whitney test in A and B and unequal variance $t$-test in C-F) indicated that there was a significant difference in the relative number of CD103+ T cells in RE BILs compared with FCD BILs, but not in peripheral blood. There was no statistical difference between the FCD cases and the RE cases with respect to the age of seizure onset and age at surgery. The linear correlation between the percent of $\mathrm{CD}_{103}{ }^{+} \mathrm{CD}^{+} \mathrm{T}$ cells in lymphocytes isolated from fresh RE and FCD brain tissue and the length of time between seizure onset and surgery was calculated $\mathbf{( G , H )}$, and showed a positive correlation between the relative number of CD103+ T cells in FCD BILs and the length of time between seizure onset and surgery. Pearson correlation coefficients, $p$-values and 95\% confidence limits (shaded areas) are shown. 


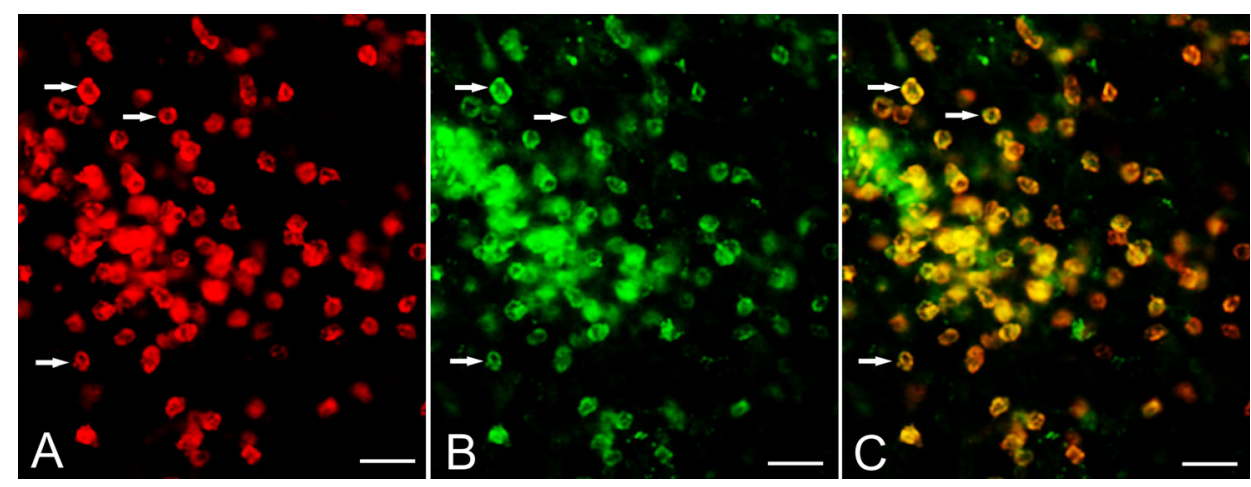

FIGURE 2 | Expression of CD103 by CD8+ T cells. Cryostat sections of brain tissue from RE surgery case RECP34 were co-stained with CD8 and CD103 antibodies; immunostaining was visualized with Alexa Fluor ${ }^{\circledR}$ conjugated secondary antibodies. (A) CD8 ${ }^{+} \mathrm{T}$ cells in brain parenchyma, (B) CD103+ staining of the same T cells (C) merged image. Arrows point to examples of CD8+ CD103+ T cells. Scale bars correspond to $50 \mu \mathrm{m}$.

cases and eight FCD cases were stained for the $\mathrm{T}_{\mathrm{RM}}$ cell marker, CD103 ( $\alpha$ E integrin subunit) together with antibodies for CD3, CD4, CD8, TCR $\alpha \beta$, and TCR $\gamma \delta$. Inflammatory markers and T cells have been identified in sections of resected brain tissue from FCD surgeries (22), although, to our knowledge, T cells have not been previously isolated from fresh FCD surgical material. The profile of T cell subtypes from the FCD brain specimens varied, although $\mathrm{CD}^{+} \alpha \beta \mathrm{T}$ cells and $\gamma \delta \mathrm{T}$ cells predominated, which we also found to be case in RE (21) (Figure S1 in Supplementary Material). As shown in Figures 1A,B, over half of the $\mathrm{CD} 8^{+} \alpha \beta$ T cells and $\gamma \delta$ T cells in the RE BIL fractions expressed CD103.

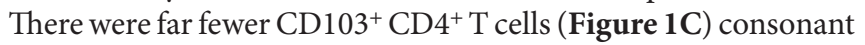
with the observation that few $\mathrm{CD} 4^{+} \mathrm{T}$ cells are found in brain parenchyma of RE patients $(7,9,23)$. The percent of $\mathrm{CD}_{103^{+}}$ $\mathrm{T}$ cells in the BIL fractions from the FCD cases was significantly lower compared with that of the RE cases (Figures 1A-C), whereas the percent of $\mathrm{CD}_{103^{+}} \mathrm{T}$ cells in the blood of both FCD and RE cases at the time of surgery was very low and not statistically different (Figure 1D).

There was no statistical difference between the FCD cases and the RE cases with respect to the age of seizure onset and age at surgery (Figures 1E,F); however, in marked contrast to the RE cases (Figure 1G), the percent of $\mathrm{CD}_{103}{ }^{+} \mathrm{T}$ cells was significantly positively correlated with the length of time from seizure onset to surgery, although the relative number of $\mathrm{T}_{\mathrm{RM}}$ cells remained low (Figure 1H).

The early $\mathrm{T}$ cell activation marker, CD69, is also expressed by $\mathrm{T}_{\mathrm{RM}}$ cells (12). We previously evaluated CD69 expression by flow cytometry and immunocytochemistry to determine whether $\mathrm{T}$ cells in RE brain tissue were activated (21). There was good agreement between the percent of $\mathrm{CD}_{103^{+}}$and $\mathrm{CD} 69^{+} \mathrm{T}$ cell subtypes in the BIL fractions from cases RECP32, RECP33, and RECP34 suggesting that all of the $\mathrm{CD} 9^{+} \mathrm{T}$ cells may be $\mathrm{T}_{\mathrm{RM}}$ cells. For cases RECP26 and RECP37, fewer $\alpha \beta$ and $\gamma \delta$ T cells were $\mathrm{CD}^{+} 9^{+}(21)$.

The expression of CD103 by T cells was confirmed by costaining cryostat sections of resected RE brain tissue with CD8 and CD103 antibodies. Figure 2 shows CD8 and CD103 immunoreactivity associated with the cell surface of the same T cells.
Serial paraffin sections of cerebral cortex from two RE and two FCD surgery cases were also stained with CD103 antibodies. In a representative field of involved RE brain parenchyma, a cluster of $\mathrm{CD}^{+} \mathrm{T}$ cells located at the border between white matter and grey matter contains $\mathrm{CD}_{103^{+}}$cells (Figures 3A,B), which are likely to be $\mathrm{T}$ cells. Individual $\mathrm{T}$ cells that appear to emanate from a blood vessel are also $\mathrm{CD}_{103}{ }^{+}$, although far fewer $\mathrm{CD} 103^{+}$cells are seen in the perivascular space of the blood vessel (Figures 3C,D). By contrast, in sections of resected brain tissue from the two FCD cases, $\mathrm{CD}^{+} \mathrm{T}$ cells are only found in association with blood vessels; few are present in brain parenchyma (Figures 3E,G). The lymphocytes in perivascular spaces do not express CD103 (Figures 3F,H).

\section{DISCUSSION}

Surgery constitutes the last option for the treatment of RE, and is only performed several months to several years after the patient first presents with seizures. If, as is suspected, the disease is triggered by an inflammatory reaction in the brain, we conjectured that some of the $\mathrm{T}$ cells found in surgically resected RE tissue may be tissue-resident memory $\mathrm{T}$ cells. By flow cytometry, we found that more than half of the $\mathrm{CD}^{+}$BILs from seven $\mathrm{RE}$ surgeries expressed CD103 irrespective of the length of time that had elapsed between the first clinical presentation of the disease and the surgery. Relatively few of the T cells isolated from eight dysplastic brain tissue specimens expressed CD103. The range of ages at the time of surgery and length of time between seizure onset and surgery were similar to the RE cases.

The positive correlation that we observed between the percent of $\mathrm{CD}_{103^{+}} \mathrm{T}$ cells isolated from FCD brain tissue, and the length of time between seizure onset and surgery indicates that $\mathrm{T}_{\mathrm{RM}}$ cells may accumulate in the brain over time in cases of FCD, albeit in relatively low numbers, possibly as a consequence of recurrent inflammation caused by the intractable seizures (24). By contrast, the high percentage of $\mathrm{T}_{\mathrm{RM}}$ cells found in $\mathrm{RE}$ brain tissue as early as 3 months after seizure onset is consistent with an acute immune response having occurred at a very early stage of the disease $(3,9)$. 


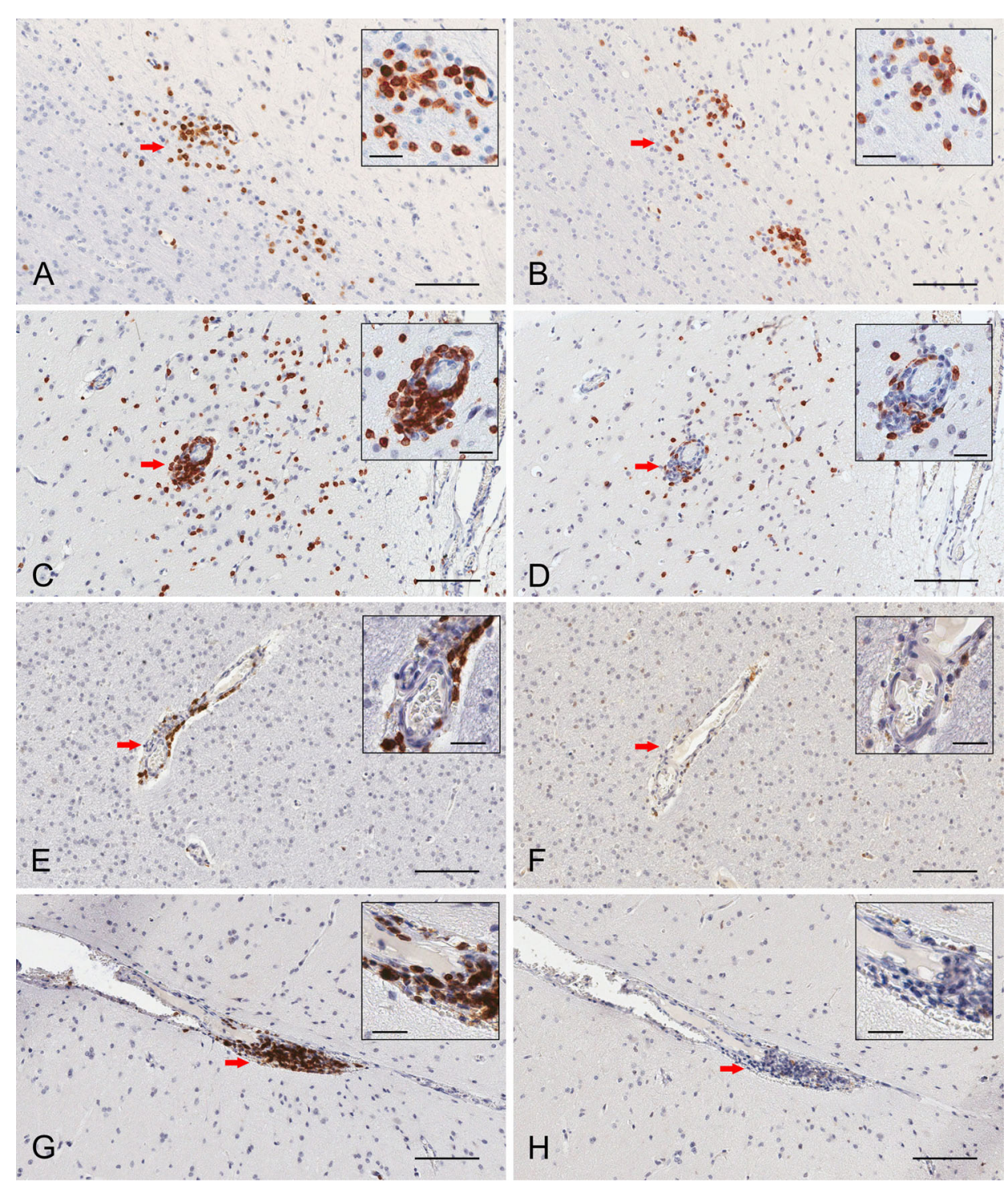

FIGURE 3 | Immunohistochemical staining of resident memory T cells in RE and FCD patient brain parenchyma. Serial $5 \mu$ m sections of brain tissue from two RE (RECP27 and RECP34) and two FCD surgery cases (CD18 and CD19) were stained with CD3 and CD103 antibodies. Immunostaining was visualized with a peroxidase-conjugated secondary antibody and 3, 3'-diaminobenzidine substrate (brown reaction product). Sections were counterstained with hematoxylin. The same clusters of CD3 ${ }^{+} \mathrm{T}$ cells (A) comprise CD103+ cells (B). Scattered T cells in brain parenchyma express CD103 (C,D), but very few T cells in perivascular space are CD103+ (C,D). In FCD, CD3+ T cells (E,G) are confined to perivascular spaces and do not express CD103 (F,H). Insets show magnified views of the areas marked by a red arrow. Scale bars correspond to 100 and $25 \mu \mathrm{m}$ (insets).

The clusters of $\mathrm{CD} 103^{+} \mathrm{T}$ cells that we observed in brain parenchyma look remarkably similar to those found in the brains of mice several weeks after an acute intranasal vesicular stomatitis virus infection (25). In this study, it appeared that $\mathrm{CD} 103^{+} \mathrm{T}$ cells were clustered around the original hotspots of viral infection even though no viral transcripts were detected at these sites (25). Other work has shown that $\mathrm{T}_{\mathrm{RM}}$ cells do not necessarily require the continuous presence of antigen to remain in place $(26,27)$. Whether an initial inflammatory event in RE is the result of an infection is not known. Cytomegalovirus, herpes simplex virus, and Epstein-Barr virus sequences have been detected in some, but not all, RE brain specimens (28-32). The partially successful treatment of a presumptive RE case with ganciclovir suggests a possible viral etiology (5), as does a patient in Japan who was diagnosed with RE following repeated infection with influenza virus (33). In this case report, the possibility of molecular mimicry as a cause of RE was suggested (33). To investigate whether a persistent viral infection may account for the recurrent immune response in RE, we searched for pathogen-related transcripts in RNA-Seq data from six RE brain tissue samples, but did not find any transcripts to known viruses (unpublished results). In skin, $\mathrm{T}_{\mathrm{RM}}$ cells are found in psoriatic lesions and sites of fixed drug eruptions (FDEs), and their presence explains the reoccurrence of lesions in the same locations (34). Psoriasis and FDEs have not been linked to known infectious agents, thus, the 
$\mathrm{T}_{\mathrm{RM}}$ cells are presumably autoreactive due to a failure of tolerogenic mechanisms, which may also be the case in RE.

In the RE brain tissue examined, it appeared that $\mathrm{T}$ cells were actively trafficking into brain parenchyma at the time of surgery (Figure 3C). By contrast, T cells in the FCD brain tissue examined were confined to perivascular spaces (Figures $\mathbf{3 E}, \mathbf{G}$ ), suggesting that the $\mathrm{T}$ cells had crossed the endothelial cell barrier, but not the glia limitans. Lymphocyte entry into the brain is a two-step process (35). Following extravasation into perivascular and leptomeningeal spaces $\mathrm{T}$ cells must subsequently cross the parenchymal basement membrane and the glia limitans to access the brain (36). In a mouse model of multiple sclerosis, this process involves a complex interplay between cytokines, chemokines, and matrix metalloproteases produced by astrocytes, microglia, nonresident macrophages, and T cells (37-39). Encounter with cells within the perivascular space that present cognate antigen may also be critical for T cell entry into the brain (40).

We have recently shown that identical V $\delta 1$ CDR3 sequences can be detected in RE and FCD brain tissue (21), suggesting that the same $\gamma \delta$ T cell clones may traffic to the brain in both diseases, but only enter the brain parenchyma in appreciable numbers in RE. This supposition could be addressed by $\mathrm{T}$ cell receptor sequence analysis of $\mathrm{CD}^{+}$cells isolated by laser capture microscopy from parenchyma and perivascular cuffs in sections of RE and FCD brain tissue. There are several case reports of overlapping RE and FCD pathology (41-46), although none of the cases in the present study were characterized by dual pathology. The presence of $\mathrm{T}_{\mathrm{RM}}$ cells may explain why $\mathrm{T}$ cells can breach the glia limiting in far greater numbers in RE than in FCD. Activation of $\mathrm{T}_{\mathrm{RM}}$ cells has been shown to recruit circulating $\mathrm{T}$ cells into an area of recurrent inflammation (47).

We conclude that the presence of $\mathrm{T}_{\mathrm{RM}}$ cells suggests that an immune response may precede the clinical presentation of $\mathrm{RE}$,

\section{REFERENCES}

1. Varadkar S, Bien CG, Kruse CA, Jensen FE, Bauer J, Pardo CA, et al. Rasmussen's encephalitis: clinical features, pathobiology, and treatment advances. Lancet Neurol (2014) 13:195-205. doi:10.1016/S1474-4422(13)70260-6

2. Pardo CA, Nabbout R, Galanopoulou AS. Mechanisms of epileptogenesis in pediatric epileptic syndromes: Rasmussen encephalitis, infantile spasms, and febrile infection-related epilepsy syndrome (FIRES). Neurotherapeutics (2014) 11:297-310. doi:10.1007/s13311-014-0265-2

3. Bien CG, Urbach H, Deckert M, Schramm J, Wiestler OD, Lassmann H, et al. Diagnosis and staging of Rasmussen's encephalitis by serial MRI and histopathology. Neurology (2002) 58:250-7. doi:10.1212/WNL.58.2.250

4. Bien CG, Tiemeier H, Sassen R, Kuczaty S, Urbach H, von Lehe M, et al. Rasmussen encephalitis: incidence and course under randomized therapy with tacrolimus or intravenous immunoglobulins. Epilepsia (2013) 54:543-50. doi:10.1111/epi.12042

5. McLachlan RS, Diosy D, Levin S. Early treatment of a progressive Rasmussen's like syndrome with ganciclovir. Can J Neurol Sci (2011) 38:296-8. doi:10.1017/ S0317167100011495

6. Bien CG, Bauer J, Deckwerth TL, Wiendl H, Deckert M, Wiestler OD, et al. Destruction of neurons by cytotoxic T cells: a new pathogenic mechanism in Rasmussen's encephalitis. Ann Neurol (2002) 51:311-8. doi:10.1002/ana.10100

7. Prayson RA, Frater JL. Rasmussen encephalitis: a clinicopathologic and immunohistochemical study of seven patients. Am JClin Pathol (2002) 117:776-82. doi:10.1309/AD8R-560C-4V11-C5E2 and may account for the difference between RE and FCD with respect to the extent of $\mathrm{T}$ cell infiltration into the brain seen at the time of surgery. We speculate that local reactivation of $\mathrm{T}_{\mathrm{RM}}$ cells, possibly triggered by seizure-induced inflammation (24), recruits antigen-experienced or newly primed $\mathrm{T}$ cells into the brain (11), thus perpetuating a chronic inflammatory condition, and progressive destruction of brain tissue. The presence of $\mathrm{T}_{\mathrm{RM}}$ cells may also explain why, once established, any recurrent immune reaction remains confined to one side of the brain. Treatments designed to block $\mathrm{T}$ cell entry into the brain or egress from lymph nodes may not be completely effective if reactivated $\mathrm{T}_{\mathrm{RM}}$ cells are directly involved in the immunopathology, as was shown to be the case in psoriasis (34).

\section{AUTHOR CONTRIBUTIONS}

GO designed the study, carried out the flow cytometry, analyzed the data, and drafted the manuscript. JC and MH isolated lymphocytes and performed immunocytochemistry, TC coordinated the collection and processing of surgical specimens, HV provided tissue sections and helped draft the manuscript, and GM provided surgical specimens and helped draft the manuscript.

\section{ACKNOWLEDGMENTS}

This work was supported by The RE Children's Project, NIH R01 NS083823 (GM), and University of California Pediatric Neuropathology Consortium (HV).

\section{SUPPLEMENTARY MATERIAL}

The Supplementary Material for this article can be found online at http://journal.frontiersin.org/article/10.3389/fimmu.2016.00064

8. Wirenfeldt M, Clare R, Tung S, Bottini A, Mathern GW, Vinters HV. Increased activation of Iba1+ microglia in pediatric epilepsy patients with Rasmussen's encephalitis compared with cortical dysplasia and tuberous sclerosis complex. Neurobiol Dis (2009) 34:432-40. doi:10.1016/j.nbd.2009.02.015

9. Pardo CA, Vining EP, Guo L, Skolasky RL, Carson BS, Freeman JM. The pathology of Rasmussen syndrome: stages of cortical involvement and neuropathological studies in 45 hemispherectomies. Epilepsia (2004) 45:516-26. doi:10.1111/j.0013-9580.2004.33103.x

10. Shin H, Iwasaki A. Tissue-resident memory T cells. Immunol Rev (2013) 255:165-81. doi:10.1111/imr.12087

11. Schenkel JM, Masopust D. Tissue-resident memory T cells. Immunity (2014) 41:886-97. doi:10.1016/j.immuni.2014.12.007

12. Farber DL, Yudanin NA, Restifo NP. Human memory T cells: generation, compartmentalization and homeostasis. Nat Rev Immunol (2014) 14:24-35. doi:10.1038/nri3567

13. Bevan MJ. Memory T cells as an occupying force. Eur JImmunol (2011) 41:1192-5. doi:10.1002/eji.201041377

14. Gebhardt T, Mackay LK. Local immunity by tissue-resident CD8(+) memory T cells. Front Immunol (2012) 3:340. doi:10.3389/fimmu.2012.00340

15. Mackay LK, Rahimpour A, Ma JZ, Collins N, Stock AT, Hafon ML, et al. The developmental pathway for CD103(+)CD8+ tissue-resident memory T cells of skin. Nat Immunol (2013) 14:1294-301. doi:10.1038/ni.2744

16. Graham JB, Da Costa A, Lund JM. Regulatory T cells shape the resident memory $\mathrm{T}$ cell response to virus infection in the tissues. J Immunol (2014) 192:683-90. doi:10.4049/jimmunol.1202153 
17. Lokensgard JR, Schachtele SJ, Mutnal MB, Sheng WS, Prasad S, Hu S. Chronic reactive gliosis following regulatory $\mathrm{T}$ cell depletion during acute MCMV encephalitis. Glia (2015) 63:1982-96. doi:10.1002/glia.22868

18. Cepek KL, Shaw SK, Parker CM, Russell GJ, Morrow JS, Rimm DL, et al. Adhesion between epithelial cells and T lymphocytes mediated by E-cadherin and the alpha Ebeta 7 integrin. Nature (1994) 372:190-3. doi:10.1038/372190a0

19. Bergsbaken T, Bevan MJ. Proinflammatory microenvironments within the intestine regulate the differentiation of tissue-resident CD8(+) T cells responding to infection. Nat Immunol (2015) 16:406-14. doi:10.1038/ni.3108

20. Franciszkiewicz K, Le Floc'h A, Boutet M, Vergnon I, Schmitt A, MamiChouaib F. CD103 or LFA-1 engagement at the immune synapse between cytotoxic T cells and tumor cells promotes maturation and regulates T-cell effector functions. Cancer Res (2013) 73:617-28. doi:10.1158/0008-5472.CAN-12-2569

21. Owens GC, Erickson KL, Malone CC, Pan C, Huynh MN, Chang JW, et al. Evidence for the involvement of gamma delta $\mathrm{T}$ cells in the immune response in Rasmussen encephalitis. J Neuroinflammation (2015) 12:134. doi:10.1186/ s12974-015-0352-2

22. Iyer A, Zurolo E, Spliet WG, van Rijen PC, Baayen JC, Gorter JA, et al. Evaluation of the innate and adaptive immunity in type I and type II focal cortical dysplasias. Epilepsia (2010) 51:1763-73. doi:10.1111/j.1528-1167.2010.02547.x

23. Owens GC, Huynh MN, Chang JW, McArthur DL, Hickey MJ, Vinters HV, et al. Differential expression of interferon-gamma and chemokine genes distinguishes Rasmussen encephalitis from cortical dysplasia and provides evidence for an early Th1 immune response. J Neuroinflammation (2013) 10:56. doi:10.1186/1742-2094-10-56

24. Vezzani A, Aronica E, Mazarati A, Pittman QJ. Epilepsy and brain inflammation. Exp Neurol (2013) 244:11-21. doi:10.1016/j.expneurol.2011.09.033

25. Wakim LM, Woodward-Davis A, Bevan MJ. Memory T cells persisting within the brain after local infection show functional adaptations to their tissue of residence. Proc Natl Acad Sci U S A (2010) 107:17872-9. doi:10.1073/pnas.1010201107

26. Casey KA, Fraser KA, Schenkel JM, Moran A, Abt MC, Beura LK, et al. Antigen-independent differentiation and maintenance of effector-like resident memory T cells in tissues. J Immunol (2012) 188:4866-75. doi:10.4049/ jimmunol.1200402

27. Mackay LK, Stock AT, Ma JZ, Jones CM, Kent SJ, Mueller SN, et al. Long-lived epithelial immunity by tissue-resident memory T (TRM) cells in the absence of persisting local antigen presentation. Proc Natl Acad Sci U S A (2012) 109:7037-42. doi:10.1073/pnas.1202288109

28. Walter GF, Renella RR. Epstein-Barr virus in brain and Rasmussen's encephalitis. Lancet (1989) 1:279-80. doi:10.1016/S0140-6736(89)91292-0

29. Power C, Poland SD, Blume WT, Girvin JP, Rice GP. Cytomegalovirus and Rasmussen's encephalitis. Lancet (1990) 336:1282-4. doi:10.1016/01406736(90)92965-K

30. Vinters HV, Wang R, Wiley CA. Herpesviruses in chronic encephalitis associated with intractable childhood epilepsy. Hum Pathol (1993) 24:871-9. doi:10.1016/0046-8177(93)90137-6

31. Atkins MR, Terrell W, Hulette CM. Rasmussen's syndrome: a study of potential viral etiology. Clin Neuropathol (1995) 14:7-12.

32. Jay V, Becker LE, Otsubo H, Cortez M, Hwang P, Hoffman HJ, et al. Chronic encephalitis and epilepsy (Rasmussen's encephalitis): detection of cytomegalovirus and herpes simplex virus 1 by the polymerase chain reaction and in situ hybridization. Neurology (1995) 45:108-17. doi:10.1212/WNL.45.1.108

33. Takahashi Y, Matsuda K, Kubota Y, Shimomura J, Yamasaki E, Kudo T, et al. Vaccination and infection as causative factors in Japanese patients with Rasmussen syndrome: molecular mimicry and HLA class I. Clin Dev Immunol (2006) 13:381-7. doi:10.1080/17402520600589522
34. Clark RA. Skin-resident T cells: the ups and downs of on site immunity. J Invest Dermatol (2010) 130:362-70. doi:10.1038/jid.2009.247

35. Engelhardt B, Ransohoff RM. Capture, crawl, cross: the T cell code to breach the blood-brain barriers. Trends Immunol (2012) 33:579-89. doi:10.1016/j. it.2012.07.004

36. Owens T, Bechmann I, Engelhardt B. Perivascular spaces and the two steps to neuroinflammation. J Neuropathol Exp Neurol (2008) 67:1113-21. doi:10.1097/NEN.0b013e31818f9ca8

37. Engelhardt B, Sorokin L. The blood-brain and the blood-cerebrospinal fluid barriers: function and dysfunction. Semin Immunopathol (2009) 31:497-511. doi:10.1007/s00281-009-0177-0

38. Larochelle C, Alvarez JI, Prat A. How do immune cells overcome the blood-brain barrier in multiple sclerosis? FEBS Lett (2011) 585:3770-80. doi:10.1016/j.febslet.2011.04.066

39. Song J, Wu C, Korpos E, Zhang X, Agrawal SM, Wang Y, et al. Focal MMP-2 and MMP-9 activity at the blood-brain barrier promotes chemokineinduced leukocyte migration. Cell Rep (2015) 10:1040-54. doi:10.1016/j. celrep.2015.01.037

40. Bartholomaus I, Kawakami N, Odoardi F, Schlager C, Miljkovic D, Ellwart JW, et al. Effector T cell interactions with meningeal vascular structures in nascent autoimmune CNS lesions. Nature (2009) 462:94-8. doi:10.1038/ nature 08478

41. Yacubian EM, Rosemberg S, Garrido Neto TL, Marie SK, Valerio RM, Jorge CL. Rasmussen encephalitis associated with segmental vitiligo of the scalp: clinicopathologic report. JChild Neurol (2001) 16:374-7. doi:10.1177/088307380101600513

42. Hart YM, Andermann F, Robitaille Y, Laxer KD, Rasmussen T, Davis R. Double pathology in Rasmussen's syndrome: a window on the etiology? Neurology (1998) 50:731-5. doi:10.1212/WNL.50.3.731

43. Palmer CA, Geyer JD, Keating JM, Gilliam F, Kuzniecky RI, Morawetz RB, et al. Rasmussen's encephalitis with concomitant cortical dysplasia: the role of GluR3. Epilepsia (1999) 40:242-7. doi:10.1111/j.1528-1157.1999.tb02082.x

44. Takei H, Wilfong A, Malphrus A, Yoshor D, Hunter JV, Armstrong DL, et al. Dual pathology in Rasmussen's encephalitis: a study of seven cases and review of the literature. Neuropathology (2010) 30:381-91. doi:10.1111/j.1440-1789.2009.01079.x

45. Prayson RA. Dual pathology in Rasmussen's encephalitis: a report of coexistent focal cortical dysplasia and review of the literature. Case Rep Pathol (2012) 2012:569170. doi:10.1155/2012/569170

46. O’Rourke DJ, Bergin A, Rotenberg A, Peters J, Gorman M, Poduri A, et al. Rasmussen's encephalitis presenting as focal cortical dysplasia. Epilepsy Behav Case Rep (2014) 2:86-9. doi:10.1016/j.ebcr.2014.01.009

47. Schenkel JM, Fraser KA, Vezys V, Masopust D. Sensing and alarm function of resident memory CD8(+) T cells. Nat Immunol (2013) 14:509-13. doi:10.1038/ni0813-876c

Conflict of Interest Statement: The authors declare that the research was conducted in the absence of any commercial or financial relationships that could be construed as a potential conflict of interest.

Copyright (c) 2016 Owens, Chang, Huynh, Chirwa, Vinters and Mathern. This is an open-access article distributed under the terms of the Creative Commons Attribution License (CC BY). The use, distribution or reproduction in other forums is permitted, provided the original author(s) or licensor are credited and that the original publication in this journal is cited, in accordance with accepted academic practice. No use, distribution or reproduction is permitted which does not comply with these terms. 